\title{
Rapid, ultra-local adaptation facilitated by phenotypic plasticity
}

\author{
Syuan-Jyun Sun ${ }^{1 *}$, Andrew M. Catherall ${ }^{1}$, Sonia Pascoal ${ }^{1}$, Benjamin J. M. Jarrett ${ }^{1,2}$, Sara \\ E. Miller ${ }^{3}$, Michael J. Sheehan ${ }^{3}$, Rebecca M. Kilner ${ }^{1}$ \\ ${ }^{1}$ Department of Zoology, University of Cambridge, Downing Street, Cambridge, CB2 3EJ, UK \\ 2 Department of Entomology, Michigan State University, 288 Farm Lane Room 243, East \\ Lansing, MI 48824, USA \\ ${ }^{3}$ Department of Neurobiology and Behavior, Cornell University, 215 Tower Road, Ithaca, NY \\ 14853, USA
}

*Corresponding author: Syuan-Jyun Sun,

Phone: 01223 (3)34466

e-mail: sjs243@,cam.ac.uk

Keywords: interspecific competition, phenotypic plasticity, plasticity-led evolution, burying beetles, Nicrophorus vespilloides, niche expansion, local adaptation. 


\section{Abstract \\ 2 Models of 'plasticity-first' evolution are attractive because they explain the rapid 3 evolution of new complex adaptations. Nevertheless, it is unclear whether plasticity can \\ 4 still facilitate rapid evolution when diverging populations are connected by gene flow. \\ 5 Here we show how plasticity has generated adaptive divergence in fecundity in wild populations of burying beetles Nicrophorus vespilloides, which are still connected by gene flow, which occupy distinct Cambridgeshire woodlands that are just $2.5 \mathrm{~km}$ apart and which diverged from a common ancestral population c. 1000-4000 years ago. We show that adaptive divergence is due to the coupling of an evolved increase in the elevation of the reaction norm linking clutch size to carrion size (i.e. genetic accommodation) with plastic secondary elimination of surplus offspring. Working in combination, these two processes have facilitated rapid adaptation to fine-scale environmental differences, despite ongoing gene flow.}

\section{Introduction}

Understanding the scale and pace of local adaptation is a long-standing problem in evolutionary biology that has acquired new significance for predicting how natural populations will respond to man-made environmental change ${ }^{1-6}$. In theory, phenotypic plasticity can potentially both accelerate the pace of evolution, and fine-tune the scale of local adaptation, through two distinct processes. The extent of phenotypic plasticity in any trait is described by a reaction norm, which relates environmental variation to the phenotype it induces. 'Plasticity-first' evolution can speed up the pace of evolutionary change in complex traits because the shape, slope and elevation of a reaction norm each have genetic components, upon which selection can act ${ }^{1-6}$. Recent experimental work on natural populations has shown that selection in a new environment can greatly reduce the slope of the reaction norm, causing the constitutive expression of novel, canalised traits ${ }^{7,8}$. New adaptations can therefore evolve through the 'genetic assimilation' ( $\left.s e n s u^{9}\right)$ of traits that were once induced environmentally.

Genetic assimilation yields rapid change but is predicted to occur only when there is

30 little or no gene flow between populations that inhabit different local environments ${ }^{10-12}$.

31 While gene flow still persists, theory predicts that selection will instead act to maintain

32 plasticity in adaptive traits ${ }^{11,12}$. Plasticity is adaptive under these conditions because it 33 'forgives' costly mistakes incurred through the expression of locally maladaptive traits.

34 Nevertheless, local adaptation through genetic change is still possible, if selection fine-tunes 
35 the slope or elevation of the reaction norm within each population to match local conditions

36 through genetic accommodation ${ }^{13,14}$. However, whether this mechanism is at work in natural animal populations is unclear (but see $^{15}$ for evidence from a plant species).

We tested whether plasticity has facilitated recent, ultra-local adaptation in wild populations of burying beetles Nicrophorus vespilloides. We focused on populations occupying Gamlingay Wood and Waresley Wood in Cambridgeshire, UK, which are c. 2.5 $\mathrm{km}$ apart. We have previously shown that the two beetle populations cannot be differentiated at neutral genetic markers, indicating there is ongoing gene flow ${ }^{16}$. Gamlingay Wood and Waresley Wood have existed as distinct woodlands since at least 1086 because they are both recorded in the Domesday Book (a land survey commissioned by William the Conqueror). However, until 3000-4000 years they were almost certainly connected as part of the 'Wild Wood', the ancient forest that once covered England but which was deforested from the Bronze Age onwards ${ }^{17}$.

Burying beetles (Nicrophorus spp.) breed on small dead vertebrates, such as rodents, and it is common for several Nicrophorus species to co-exist within the same woodland. Competition for carrion partitions the carrion niche so that larger burying beetle species tend to breed on larger carrion, while the smallest species ( $N$. vespilloides in the UK) typically uses the smallest carrion ${ }^{18-21}$. Burying beetles match the number of eggs they lay to the size of the carcass they obtain ${ }^{22}$, and facultatively cull any surplus larvae through partial filial cannibalism $^{23}$. The adaptive clutch size and brood size therefore depend on the size of the carrion that is routinely available for reproduction.

Here we show that the burying beetle guilds differ between the Gamlingay and Waresley Woods, and that this changes the range in carrion size available for $N$. vespilloides to breed upon. We demonstrate corresponding adaptive divergence in levels of fecundity shown by $N$. vespilloides from each population, and show how plasticity has facilitated such rapid adaptive divergence on such an ultra-local scale.

\section{Results}

\section{The Nicrophorus guild differs between Gamlingay and Waresley Woods}

In general, we found that the two woodlands harboured a similar number of Nicrophorus beetles: we caught a total of 1873 Nicrophorus individuals in Gamlingay Wood over the four-year sampling period compared with 1806 Nicrophorus individuals in Waresley Wood. 
each Nicrophorus species differed between the two woods (species x woodland interaction: $\chi^{2}$ $=142.68$, d.f. $=4, p<0.001)$. N. vespilloides was by far the most abundant in each woodland, comprising 80.6\% (1510 individuals) of all Nicrophorus beetles trapped in Gamlingay Wood and 93.9\% (1695 individuals) of those trapped in Waresley Wood. Both sites also contained stable populations of the largest species, N. humator (Fig. 1b; Supplementary Tables 1 and Supplementary Tables 2). Only Gamlingay Wood contained populations of intermediatesized $N$. interruptus and N. investigator in all four years of the study (Fig. 1b; Supplementary Tables 1 and Supplementary Tables 2), and in significantly greater abundance in Waresley Woods (Tukey HSD, $z=7.90, p<0.001$ and $z=5.80, p<0.001$, respectively). The Nicrophorus guild is therefore significantly different between the two woodlands (PERMANOVA (permutational multivariate analysis of variance) test $F=0.024, p<0.001$; Supplementary Fig. 1b).

\section{No evidence for divergence in the small mammal population between Gamlingay and} Waresley Woods

We sampled the small mammal population in Gamlingay and Waresley Woods to estimate the abundance and type of carrion that might be available to the burying beetles to breed upon (see Methods). In Gamlingay, 32 animals were caught across 50 trap sessions (23 new catches and 9 recaptures); in Waresley 41 animals were caught across 50 trap sessions (30 new catches and 11 recaptures). Across both woods, bank voles (Myodes glareolus; range: 15-40 g) and wood mice (Apodemus sylvaticus; range: 13-27 g) were the dominant species, constituting $53 \%$ and $43 \%$ of all trapped mammals respectively. There was no difference in the mean body mass of small mammals sampled between the two sites $\left(\chi^{2}=0.19\right.$, d.f. $=1, p=$ 0.661; Supplementary Fig. 2).

\section{The Gamlingay guild is 'ancestral', whereas the Waresley guild is derived}

We conclude from these data that there are approximately similar numbers of Nicrophorus beetles within each woodland competing for an approximately similar size, abundance and type of rodent carrion to breed upon. The key difference lies in the number of burying beetle species in each wood.

We further infer from the ecological data that the more speciose burying beetle guild in Gamlingay Wood more closely approximates the ancestral burying beetle guild that was present in the 'Wild Wood', whereas the guild in Waresley Wood represents a more recent, derived condition. This is because burying beetle guilds in pristine ancient forests in North 
103 America are more speciose than those present in degraded woodlands ${ }^{24}$, in keeping with the

104 general observation that there is a positive relationship between habitat size and species

105 richness ${ }^{25}$. Furthermore, smaller-bodied generalist carrion beetles are more likely to survive

106 in fragmented forests ${ }^{24}$.

107

108 Niche expansion by N. vespilloides beetles in Waresley Wood

109 The ecological data additionally suggest that in Gamlingay Wood, N. vespilloides is more

110 likely to be confined to breeding only on smaller carrion. In general, larger Nicrophorus

111 species appear to be under selection to breed on larger carcasses ${ }^{26,27}$, forcing smaller beetles

112 to breed on smaller carrion. Accordingly, $N$. vespilloides is more than twice as likely to be

113 found on small carcasses than on large carcasses in continental forests, which are rich in

114 Nicrophorus species ${ }^{21}$. In Waresley Wood, by contrast, $N$. vespilloides is more likely to breed

115 on larger carrion as well because it more rarely faces competition from $N$. interruptus and $N$.

116 investigator for larger carcasses (woodland effect: $\chi^{2}=27.75$, d.f. $=1, p<0.001$; Fig. 1c; see

117 also ref. ${ }^{18}$ ).

118 By measuring reproductive performance in the laboratory, we determined the carrion

119 niche occupied by the following species, in decreasing order of size (Fig. 1b): N. investigator

120 (from Gamlingay Wood), N. interruptus (from Gamlingay Wood), and N. vespilloides beetles

121 (from both Gamlingay and Waresley Woods) (see Methods). For each species, we

122 experimentally varied the size of carrion available for reproduction, presenting pairs with

123 either a small mouse carcass (range: 12-20 g; mean \pm S.E.M: $16.80 \pm 0.55 \mathrm{~g}$ ) or a large

124 mouse carcass (range: $25-31 \mathrm{~g}$; mean \pm S.E.M: $28.27 \pm 0.53 \mathrm{~g}$; natural carcass range $=8.5-41$

$125 \mathrm{~g})$. To quantify reproductive performance on each carcass size, we measured 'carcass use

126 efficiency', calculated by dividing the total brood mass at the end of larval development

127 (measured when larvae had dispersed from the carcass) by the size of the carcass the brood

128 was reared on. We predicted that if there is local adaptation, N. investigator and $N$.

129 interruptus should each exhibit greatest efficiency when breeding on a large carcass, while $N$.

130 vespilloides from Gamlingay Wood should exhibit greatest efficiency when breeding on a

131 small carcass. $N$. vespilloides from Waresley Wood should be more efficient at breeding on a

132 large carcass than N. vespilloides from Gamlingay Wood.

133 We found that the efficiency of converting the carcass into larvae varied with carcass

134 size, but in a different way for each Nicrophorus species (carcass size x Nicrophorus species

135 interaction term: $\chi^{2}=28.85$, d.f. $=3, p<0.001$; Fig. 2 and Supplementary Table 3). $N$.

136 investigator exhibited greater efficiency when breeding on large carcasses rather than on 
137 small carcasses $(t=3.51, p<0.001)$. N. interruptus was similarly efficient when breeding on

138 both large and small carcasses $(t=0.99, p=0.325)$. These species are therefore adapted to

139 breed on larger carrion. In contrast, $N$. vespilloides from Gamlingay Wood exhibited greatest

140 reproductive efficiency on small carcasses $(t=-4.16, p<0.001)$. Waresley beetles were

141 similarly efficient to Gamlingay beetles when breeding on a small carcass $(t=0.58, p=$

1420.938 ) but were significantly more efficient at breeding on a large carcass than $N$.

143 vespilloides from Gamlingay $\operatorname{Wood}(t=-3.11, p=0.011)$. We conclude that the population of

$144 N$. vespilloides in Waresley Wood has adaptively expanded its carrion niche to breed on

145 larger carcasses, in response to the loss of competition for larger carrion from $N$. interruptus

146 and $N$. investigator.

Niche expansion by Waresley $N$. vespilloides is due to divergent reaction norms

149 To test whether niche expansion by Waresley $N$. vespilloides was facilitated by genetic

150 accommodation, we generated reaction norms relating carcass size to clutch size for $N$.

151 vespilloides from the two woodland populations (see Methods). From the results in Fig. 2, we

152 predicted that the reaction norm for Waresley $N$. vespilloides would be significantly steeper

153 than the reaction norm for Gamlingay $N$. vespilloides. In fact, we found that the reaction

154 norms differed in their intercept rather than in their slope (Fig. 3a). Although female $N$.

155 vespilloides from both woodlands laid more eggs when given a larger carcass to breed upon

156 (carcass size effect: $\chi^{2}=10.97$, d.f. $=1, p<0.001$; Supplementary Table 4), Waresley $N$.

157 vespilloides consistently laid more eggs than Gamlingay $N$. vespilloides (woodland effect: $\chi^{2}$

$158=21.07$, d.f. $=1, p<0.001$; Supplementary Table 4), irrespective of carcass size (carcass size

$159 \mathrm{x}$ woodland interaction: $\chi^{2}=1.44$, d.f. $=1, p=0.231$ ) or female size (woodland $\mathrm{x}$ female size

160 interaction: $\chi^{2}=1.30$, d.f. $=1, p=0.254$ ).

161 Likewise, although female $N$. vespilloides from both woodlands laid smaller eggs when

162 given a larger carcass to breed upon (carcass size effect: $\chi^{2}=5.90$, d.f. $=1, p=0.015$; Fig.

$1633 \mathrm{~b}$ ), Waresley $N$. vespilloides consistently laid smaller eggs than Gamlingay $N$. vespilloides

164 (woodland effect: $\chi^{2}=4.59$, d.f. $=1, p=0.032$ ), irrespective of carcass size (carcass size $\mathrm{x}$

165 woodland interaction: $\chi^{2}=0.33$, d.f. $\left.=1, p=0.565\right)$. Mean egg volume per clutch did not

166 predict mean larval mass per brood at dispersal $\left(\chi^{2}=0.28\right.$, d.f. $\left.=1, p=0.595\right)$, regardless of

167 the population of origin. This suggests that any under-provisioning of eggs is compensated by

168 the over-abundance of resources available on the carcass after hatching ${ }^{28,29}$. 
171 When we related brood size (measured at the end of reproduction) to carcass size, we found

172 the predicted difference between Gamlingay and Waresley N. vespilloides in the slope of this

173 reaction norm (woodland $\mathrm{x}$ carcass size interaction: $\chi^{2}=4.80$, d.f. $=1, p=0.029$; Fig. 4;

174 Supplementary Table 4). On a large carcass, Waresley N. vespilloides produced more larvae

175 than Gamlingay N. vespilloides $(z=-1.97, p=0.049)$, whereas on a small carcass the number

176 of larvae produced did not differ between the two populations $(z=0.76, p=0.447)$.

177 Therefore Waresley N. vespilloides lays more eggs on a small carcass than Gamlingay $N$.

178 vespilloides, but there is plastic culling of surplus offspring after egg-laying, probably due to 179 partial filial cannibalism ${ }^{23}$.

180 In short, Waresley N. vespilloides has evolved the ability to lay extra eggs whatever the 181 size of the carcass it locates for reproduction. This brings fitness gains if the beetle locates a 182 large carcass and correspondingly increases the efficiency with it converts carrion into 183 offspring. Yet it brings fitness costs if the beetle instead finds a small carcass to breed upon, 184 because there is a pronounced trade-off between larval number and larval size ${ }^{30}$ and small 185 larvae have markedly lower fitness ${ }^{31}$. However, with a secondary mechanism for dispensing 186 with excess young on smaller carcasses (probably filial cannibalism), these costs are

187 eliminated. We suggest that genetic accommodation of the reaction norm relating clutch size 188 to carrion has evolved and is adaptive only because there is an accompanying plastic 189 mechanism for correcting the over-production of offspring on a small carcass. The same 190 mechanism can also prevent costly excess fecundity if there is gene flow from Waresley to 191 Gamlingay.

Divergence at loci associated with oogenesis in N. vespilloides from Gamlingay v. Waresley

195 To be certain that differences in the elevation of the reaction norm were due to evolutionary

196 change, we sought evidence of associated genetic divergence. We generated low-coverage 197 whole genome sequences for 40 individuals collected from each wood $(n=80$ chromosomes 198 per population). We found minimal divergence across the genome with no instances of 199 extreme outliers (Supplementary Fig. 4), probably because the divergent traits are controlled 200 by many loci. This is typical for behavioural and life history traits and consistent with the 201 predicted quantitative genetic basis of genetic accommodation ${ }^{6}$. The highest $F s t$-windows in 202 the genome showed only modest absolute values of divergence. Nevertheless, they were 203 extreme outliers due to the otherwise consistently low pattern of $F s t$ between populations (see 204 Methods). 
By comparing differentiation between both woodlands and a third population from $300 \mathrm{~km}$ away in Swansea, Wales, UK, we polarised the divergence between populations. We calculated all pairwise $F s t$ and assigned the relative divergence of each population using population branch statistics (PBS) to understand which population was driving divergence across the genome ${ }^{32,33}$. Not surprisingly, the distant Welsh population showed the highest genome-wide PBS. We found that population from Waresley Wood showed higher differentiation compared to the population from Gamlingay Wood (mean PBS: Waresley $=$

2120.0074 , Gamlingay $=0.0056$, Wales $=0.0109)$. These analyses therefore support the

213 ecological data in indicating that the Gamlingay N. vespilloides represents the ancestral

214 condition, whereas the Waresley N. vespilloides are the derived population (Supplementary

215 Fig. 5).

216 To visualise the relative divergence between populations across the genome, we 217 generated a scatterplot of the PBS values for $2 \mathrm{~kb}$ non-overlapping windows for each

218 population (Fig. 5a). The analysis highlighted multiple potential candidate genes associated 219 with the differences in egg-laying behaviour, again consistent with this trait being controlled

220 by many loci of small effect. For example, homologs of three of the highly differentiated

221 genes in the Waresley Wood population - obg-like ATPase, transmembrane protein 214, and 222 liprin-alpha - show elevated expression in the ovaries of fruit flies ${ }^{34}$ and other arthropods ${ }^{35}$, 223 suggesting a plausible role in regulating egg production. Another gene, kekkon 1, is a

224 transmembrane protein known to regulate the activity of the epidermal growth factor receptor 225 (EGFR) during oogenesis in Drosophila ${ }^{36,37}$.

226 Finally, we asked whether genes involved in oogenesis generally showed elevated levels 227 of differentiation in each population, in comparison with the rest of the genome. For each population, we ranked genes by the highest PBS score in 500bp windows overlapping with the gene-body and conducted a gene set enrichment analysis for each population. $N$. vespilloides from both Waresley and Gamlingay Woods showed enrichment in multiple GO

231 terms associated with ovaries and oogenesis (Table 1).

\section{Discussion}

234 Our analyses support the three principle criteria required to show evidence for plasticity-first 235 evolution ${ }^{6}$. We show that the ancestral reaction norm linking carrion size to clutch size has 236 evolved to have a greater intercept in $N$. vespilloides from Waresley Wood. This change has 237 enabled Waresley N. vespilloides beetles to expand their carrion niche in the absence of rival 238 congenerics. It is adaptive because Waresley $N$. vespilloides are now more effective than 
239 Gamlingay $N$. vespilloides at converting carrion that ranges widely in size into offspring.

240 Whereas previous analyses of plasticity-first evolution in wild animal populations have

241 emphasised how new adaptations can evolve from the genetic assimilation of plastic traits ${ }^{6-}$

$242 \quad 8,38$, our study is different in showing how adaptive traits in nature can also result from

243 genetic accommodation.

244 Importantly, plasticity not only precedes the evolution of new local adaptations but also

245 provides a secondary correcting mechanism that ameliorates the costs of expressing these

246 new adaptations in the wrong local environment. Indeed, the presence of a plastic secondary

247 correcting mechanism is key to explaining how there has been genetic accommodation of the

248 reaction norm in $N$. vespilloides from Waresley Woods, despite gene flow with $N$.

249 vespilloides from Gamlingay Woods. We have demonstrated that when evolution by genetic

250 accommodation in one trait is coupled with a second plastically expressed correcting

251 mechanism, then new adaptations can emerge rapidly and on an ultra-fine scale. We suggest

252 that whenever these two mechanisms operate together, in two related traits, there is immense

253 potential for rapid evolutionary change that is finely tuned to local environmental conditions.

\section{Methods}

\section{The history of Gamlingay and Waresley Woods}

257 We focused on two woodlands: Gamlingay Wood (Latitude: 52.15555; Longitude:

$258-0.19286^{\circ}$ ), and Waresley Wood (Latitude: $52.17487^{\circ}$; Longitude: $-0.17354^{\circ}$ ). They are

259 woodland islands of approximately the same size (c 50ha) in a landscape dominated by arable

260 farming (Supplementary Fig. 1a). In common with other woodlands recorded in the

261 Domesday book, these woods have stayed approximately the same size since $1086^{39}$.

262 Gamlingay Wood was acquired and managed by Merton College, Oxford for c. 800 years ${ }^{40}$.

263 Its ecology was described in detail in $1912^{40}$. The modern history of Waresley Wood is less

264 well-known ${ }^{39,41}$. Both sites are now designated as 'ancient woodland' and are managed by the

265 Bedfordshire, Cambridgeshire and Northamptonshire Wildlife Trusts.

\section{Competition for carrion in Gamlingay and Waresley Woods}

268 Burying beetle trapping

269 Each year from 2014-2017 we set five beetle traps per woodland, at exactly the same five

270 locations within each wood (Supplementary Fig. 1a), and checked the contents every 2-3

271 weeks from June until October, each time rebaiting the trap with fresh compost and a dead

272 mouse. Carrion-baited soil-filled traps were suspended at each site, with traps set at least 150 
m apart from each other. We collected and identifed all the Nicrophorus spp. within each trap and measured the pronotum width (to the nearest $0.01 \mathrm{~mm}$ ) as an index of body size (see below).

We caught five species in total (in increasing order of size): $N$. vespilloides, $N$. interruptus, $N$. vespillo, $N$. investigator and $N$. humator. However, $N$. vespillo were only caught 5 and 3 times within the four years in Gamlingay and Waresley respectively, indicating that there is no stable population of $N$. vespillo in either wood. A clear separation of the guild structure between the woods can be seen for each sampling time across the four years in NMDS (nonmetric multidimensional scaling) ordination (Supplementary Fig. 1b).

Evidence from other populations suggests that our measurements reflect long-term differences in guild structure because abundance measures of Nicrophorus are robust over time, even when there are marked change in woodland management ${ }^{40}$.

\section{Burying beetle husbandry in the lab}

After removing any phoretic mites, beetles were retained and kept individually in plastic boxes $(12 \mathrm{~cm} \times 8 \mathrm{~cm} \times 2 \mathrm{~cm})$, which were filled with moist soil in a laboratory kept at $20^{\circ} \mathrm{C}$ and on a 16:8 light to dark cycle. Beetles were fed twice a week with minced beef. We kept all field-caught individuals for at least two weeks before breeding to ensure that they were sexually mature and to reduce any variation in nutritional status. We then maintained stock populations of both Gamlingay and Waresley Woods by breeding pairs of unrelated individuals on 8-16 g mice carcasses.

\section{Size distributions of the Nicrophorus spp.}

Body size was measured for Nicrophorus spp. collected from 2014 to 2017 (except in 2016). In total, $838 \mathrm{~N}$. vespilloides, $41 \mathrm{~N}$. humator, $127 \mathrm{~N}$. interruptus, $54 \mathrm{~N}$. investigator, and $5 \mathrm{~N}$. vespillo were measured for Gamlingay Wood, whereas 824 N. vespilloides, 51 N. humator, $25 N$. interruptus, $4 N$. investigator, and $6 N$. vespillo were measured for Waresley Wood. Mean body size of Nicrophorus spp. significantly varied among species (GLMM: $\chi^{2}=$ 2069.44, d.f. $=4, p<0.001$; Supplementary Table 2). Post-hoc comparisons revealed that $N$. vespilloides was smaller than the other Nicrophorus spp. (Supplementary Table 1 and Supplementary Table 2). A Kolmogorov-Smirnov test comparing pairwise differences in Nicrophorus spp. body size frequency distribution revealed similar patterns found in differences of mean body size (Fig. 1 and Supplementary Table 5). 


\section{Mark-recapture experiment}

308 In 2014, we investigated the interconnectivity of populations of burying beetles between

309 Gamlingay and Waresley Woods using a mark-recapture survey. In total, 98 N. vespilloides,

3109 N. humator, 17 N. interruptus, 9 N. investigator, and 2 N. vespillo were marked for

311 Gamlingay Wood, whereas 113 N. vespilloides, 5 N. humator, 1 N. interruptus, 1 N.

312 investigator were marked for Waresley Wood. Beetles were marked with a numbered plastic

313 bee tag on either the right or left elytra for those found in Gamlingay or Waresley Woods

314 respectively. To identify any previously caught beetles that lost their tags, we permanently

315 marked them by cutting a small portion of the elytra (less than 2\%). All marked beetles from

316 each wood were released from a designated location at the geographic midpoint with the

317 minimum total distance to all trapping sites for Gamlingay (Latitude: $52.16294^{\circ}$; Longitude:

$318-0.18984^{\circ}$ ) and Waresley Woods (Latitude: $52.176508^{\circ}$; Longitude: $-0.156776^{\circ}$ ). We found

319 no evidence of migration between the two sites. We recaught 8 of 98 marked $N$. vespilloides

320 from Gamlingay Wood in Gamlingay Wood and 8 out of 113 marked N. vespilloides from

321 Waresley Wood in Waresley Wood. None of the other marked Nicrophorus spp. was

322 recaptured in either wood.

\section{Small mammal trapping}

325 To assess the rodent carrion available for Nicrophorus spp. reproduction, we sampled the

326 small mammal communities in the two woodlands. In general, rodent populations peak in the

327 autumn, because breeding for the year has just ceased and there has yet to be any winter-

328 induced mortality ${ }^{42}$. Sampling at this time is therefore ideal for detecting which species are

329 present and for determining their relative abundance. We placed Longworth traps in both

330 woodlands in November 2016. Traps were baited with oats and blowfly maggots (with hay

331 provided as bedding) and set in pairs within $20 \mathrm{~m}$ of each original beetle trapping site

332 (Supplementary Fig. 1a), with 10 traps set per wood. We continuously trapped rodents for

333 three days, generating 50 trap sessions per woodland. Traps were checked daily at

334 approximately 0830 and 1500 (generating a total of 30 trap sessions overnight and 20 trap

335 sessions in daylight hours). Trapped mammals were identified, weighed, sexed, marked by a

336 fur clip on either the right or left rear flank, and released in situ. Any recaptured mammal was

337 recorded in subsequent censuses. All traps were reset and rebaited immediately after

338 checking. In addition to the results reported in the main text, one yellow-necked mouse

339 (Apodemus flavicollis; range: 14-45 g) and one common shrew (Sorex araneus; range: 5-14

340 g) were caught in Waresley. We have no reason to think that the mortality of these rodent 
341 species should differ between woodlands that are in such close proximity and that are

342 subjected to similar levels of ecological management.

\section{Division of the carrion niche by Nicrophorus beetles in Gamlingay and Waresley Woods}

345 During the field seasons in 2017 and 2018, pairs of wild-caught $N$. vespilloides, $N$.

346 interruptus, and $N$. investigator were bred on either small (12-20 g; $16.80 \pm 0.55 \mathrm{~g})$ or large

347 carcasses $(25-31 \mathrm{~g} ; 28.27 \pm 0.53 \mathrm{~g})$ within a breeding box $(17 \times 12 \times 6 \mathrm{~cm})$ filled with $2 \mathrm{~cm}$

348 of moist soil. All field-caught beetles were kept for two weeks in the laboratory and fed twice

349 a week prior to breeding. In total, we established eight treatments: large $(n=47)$ and small $(n$

$350=48)$ carcasses for Gamlingay $N$. vespilloides; large $(n=42)$ and small $(n=33)$ carcasses for

351 Waresley $N$. vespilloides; large $(n=25)$ and small $(n=18)$ carcasses for $N$. interruptus; large

$352(n=9)$ and small $(n=13)$ carcasses for $N$. investigator. $N$. interruptus and $N$. investigator

353 were both drawn from Gamlingay Wood as the populations of these species in Waresley were 354 too small to be used experimentally.

355 Approximately eight days after parents are given a carcass to breed on, larvae switch

356 from aggregating on the carcass to dispersing away into the soil to pupate. When one or more

357 larvae from each brood switched their behaviour in this way, we scored the whole brood as

358 having reached the dispersal stage. At this point, all larvae were counted and total brood mass

359 was weighed to the nearest $0.001 \mathrm{~g}$. We also calculated average larval mass for each brood by

360 dividing total brood mass by number of larvae.

361 In addition to the results reported in the main text, we found that Gamlingay $N$.

362 vespilloides was less efficient on larger carcasses than both $N$. interruptus $(t=-3.92, p<$

$3630.001)$ and $N$. investigator $(t=-2.69, p=0.038)$.

Niche expansion in $N$. vespilloides by genetic accommodation

366 This experiment was conducted in the laboratory, over two blocks in 2017, using the second

367 and third descendant generations of field-caught beetles from Gamlingay and Waresley

368 Woods. By rearing beetles from both woodlands in the lab in a common garden environment

369 for at least one generation prior to testing, we minimized any residual environmental effects

370 when quantifying the reaction norm for each population. To pair beetles for reproduction, we

371 began by haphazardly casting broods into dyads when larvae had matured into adults. Within

372 each dyad, we haphazardly chose four males from one brood, and paired them with four

373 haphazardly chosen females from the second brood. Two of these pairs were then given a

374 small mouse to breed upon $(12-17 \mathrm{~g} ; 15.03 \pm 0.67 \mathrm{~g})$, while the remaining two pairs were 
375 given a large mouse to breed upon (26-31 g; 28.86 $\pm 0.67 \mathrm{~g})$. By using sibships to generate

376 pairs in this way, we were able to compare how very similar genotypes responded to the

377 opportunity to breed on either a small or large mouse. Each pair, and their mouse, was housed

378 in a clear plastic box $(17 \times 12 \times 6 \mathrm{~cm})$, with $2 \mathrm{~cm}$ depth of Miracle-Gro compost. The box

379 was placed in a dark cupboard for eight days after pairing the beetles, until larvae started to

380 disperse away from the carcass. In the second block of the experiment, we measured clutch

381 size. Fifty-six hours after we introduced the beetles to the carcass, we photographed the base

382 of each transparent breeding box. Using Digimizer ver. 5.1.0, we then counted the number of

383 visible eggs, and also measured the length (L) and width (w) of all eggs that were able to be

384 measured accurately (i.e. those that were fully visible and lying flat on the base of the box).

385 All counting and measuring of eggs was performed blind to the carcass size treatment and the

386 population from whence the breeding beetles came. Egg volume was then calculated using

387 the formula $\mathrm{V}=1 / 6 * \pi^{*} \mathrm{w}^{2 *} \mathrm{~L}$, which assumes eggs to be a prolate spheroid (following ref. ${ }^{43}$ ).

388 In both blocks, we also measured the number of larvae present at dispersal and weighed the

389 whole brood.

\section{Clutch size}

392 In total, 2518 eggs were counted across 132 breeding boxes, of which 1633 could be

393 measured. No eggs could be seen in four of these boxes, and these were excluded from

394 further analysis (hence $n=128$ ). The total number of eggs counted (observed clutch size),

395 and the number of eggs which could accurately be measured, each correlated positively with

396 brood size (number of eggs counted: $\chi^{2}=27.18$, d.f. $=1, p<0.001$; number of eggs

397 measured: $\chi^{2}=24.26$, d.f. $=1, p<0.001$ ), indicating these are accurate estimates of true

398 clutch size. The total volume of all eggs in a clutch did not differ between populations $\left(\chi^{2}=\right.$

3992.16 , d.f. $=1, p=0.141$; Supplementary Table 4$)$ or carcass size treatments $\left(\chi^{2}=2.38\right.$, d.f. $=$

$4001, p=0.123$; Supplementary Table 4).

\section{Brood size}

403 We found that when given a larger carcass for reproduction, N. vespilloides from Gamlingay

404 Wood produced only a marginally larger brood than when breeding on a small carcass $(z=$

$4051.82, p=0.068)$. By contrast, Waresley $N$. vespilloides produced significantly larger broods

406 on larger carcasses than on smaller carcasses $(z=5.53, p<0.001)$. Whether they bred on

407 small or large carcasses, the variance was similar for Gamlingay and Waresley $N$. 
vespilloides in both brood size (Bartlett's test, $p=0.615$ ) and carcass use efficiency

409 (Bartlett's test, $p=0.943$ ).

\section{Offspring size}

412 Females produced heavier larvae at dispersal when breeding on a large carcass than on a 413 small carcass $\left(\chi^{2}=139.05\right.$, d.f. $=1, p<0.001$; Supplementary Table 4$)$, irrespective of their

414 woodland of origin $\left(\chi^{2}=1.06\right.$, d.f. $=1, p=0.304$; Supplementary Table 4$)$. We could find no 415 difference in the size of adult N. vespilloides trapped in Gamlingay and Waresley Woods, $\left(\chi^{2}\right.$ $416=2.02$, d.f. $=1, p=0.156$; Supplementary Fig. 3a), even after controlling for sex $\left(\chi^{2}=1.41\right.$, 417 d.f. $=1, p=0.235)$. We could not detect any differences in body size distribution between 418 Gamlingay and Waresley $N$. vespilloides $(D=0.044, p=0.410$; Supplementary Fig. 3b).

419 Thus, given an abundance of resources for reproduction, $N$. vespilloides allocates them to 420 producing more offspring rather than larger offspring.

Divergence at loci associated with oogenesis in N. vespilloides from Gamlingay v. Waresley

\section{Woods}

424 We generated low-coverage whole genome sequences for three populations of $N$. vespilloides: from Waresley Wood, Gamlingay Wood and Swansea, Wales, UK. Twenty-two $N$. vespilloides from three ancient woodlands near Swansea in Wales were trapped by Dr Chris Cunningham in 2017. The three sites in Wales (Park Wood (Latitude: $51.57258^{\circ}$; Longitude: $-4.03096^{\circ}$ ); Clyne Valley Wood (Latitude: 51.61262 ${ }^{\circ}$ Longitude: $-4.02293^{\circ}$ ); and Caswell Bay Wood (Latitude: 51.57258 ; Longitude: $-4.03096^{\circ}$ )) are approximately 300 $\mathrm{km}$ away from our two study sites in Cambridgeshire.

DNA was individually extracted from beetle heads using the DNeasy Blood and Tissue kit (Qiagen) and subsequently quantified and quality checked using NanoDrop and Qubit. DNA was then shipped to Cornell University, where libraries were prepared using partial reactions of a Nexterra kit by the Cornell Genomics Core. Libraries were subsequently sequenced by Novogene (Davis, CA, USA) at an average depth of approximately $5 \mathrm{x}$ coverage. Paired-end $550 \mathrm{bp}$ insert libraries were prepared for each sample with the Nextera library preparation kit. Libraries were sequenced using the Illumina HiSeq (Novogene, Davis, $\mathrm{CA}$ ) at an average coverage of $3.4 \mathrm{X}$. Trimmomatic (v0.36) was used to removed adaptors and poor-quality sequence. Trimmed reads were mapped to the $N$. vespilloides reference genome using the Burrows-Wheeler Aligner (v0.7.13) ${ }^{44}$. SNPs were identified using Picard (v2.8.2) and GATK (v3.6) HaplotypeCaller following best practice recommendations ${ }^{45}$. After 
442 alignment, SNPs were hard filtered using the parameters: QD $<2.0||$ SOR $>3.0 \|$ FS $>200$.

443 We used VCFtools to calculate population genetic statistics for each population. To examine

444 population structure, we generated a thinned VCF file with one SNP per 5kb and used Tassel

445 (version 5) ${ }^{46}$ to calculate generate an MDS plot. For calculation of Fst and PBS values,

446 aligned bam files were analysed in ANGSD (v 0.911$)^{47}$, which is specifically designed for

447 analysis of low-coverage genome sequencing data. Data for this project is available at the

448 NCBI Sequence Read Archive under Bioproject PRJNA530213.

449 Genes were assigned gene ontology (GO) terms using the BLAST2GO workflow

450 (v5.1.1). In brief, gene identity was determined based upon BLAST searches to the

451 Arthropod or Drosophila non-redundant protein databases and protein domains were

452 identified based on matches to Interpro database. GO terms were assigned to each gene

453 model based upon mapping results. GO terms were filtered with the "Filter Annotation by

454 GO Taxa” option to remove GO terms that are incompatible for Arthropods.

455 Population genetic summary statistics were similar for both populations (mean of $2 \mathrm{~kb}$

456 windows - Gamlingay $\mathrm{Pi}=0.0055 \pm 1.02 \mathrm{e}-5$, Tajima's $\mathrm{D}=-0.70 \pm 0.002$; Waresley $\mathrm{Pi}=$

$4570.0056 \pm 1.0 \mathrm{e}-5$, Tajima's $\mathrm{D}=-0.67 \pm 0.002)$. Consistent with previous microsatellite

458 analyses $^{16}$, we found little to no genetic differentiation between populations from Gamlingay

459 and Waresley Woods (unweighted $F s t=0.0069$; weighted $F s t=0.013$ ), strongly suggesting

460 there is ongoing gene flow between the two populations.

461 Among the few loci that diverged between the populations, the top window of

462 divergence between the two populations fell in transmembrane protein $214\left(F_{s t}=0.11, z F s t\right.$

$463=19.2, p=7.2 \mathrm{e}-82$ ), which is highly expressed in the ovaries in Drosophila melanogaster,

464 and is therefore a potential candidate gene influencing differences in N. vespilloides egg

465 laying behaviour between Gamlingay and Waresley Woods.

PBS analysis identified further candidate genes. We found that a different portion of kekl is moderately differentiated in N. vespilloides from Gamlingay Wood (Fig. 5a),

468 suggesting that differentiation related to oogenesis is not limited to $N$. vespilloides from

469 Waresley Wood. One of the stronger signals of differentiation in Waresley Wood that may

470 contribute to the phenotypic differences observed between populations is found in a serotonin

471 receptor (Fig. 5b). Serotonin has been linked to reproduction via effects on the production of

472 ecdysteroids such as juvenile hormone in multiple insects ${ }^{48-50}$. Serotonin has also been

473 related to the intensity of aggressive behaviour in contests across diverse insect groups ${ }^{51-54}$.

474 Consistent with the outlier analyses, oogenesis-related GO-terms tended to have higher

475 enrichment scores in N. vespilloides from Waresley Wood compared to Gamlingay Wood 
(Table 1). The gene enrichment analysis also revealed local divergence between beetles from

477 Waresley and Gamlingay Woods at genes associated with other traits, including learning and

478 memory and sensory systems (Supplementary Data 1).

\section{$480 \quad$ Statistical analyses}

481 All statistical analyses were performed in R version 3.4.3 (R Development Core Team), with 482 NMDS in the package vegan, GLM and GLMM in the package lme $4^{55}$, and Tukey's HSD post 483 hoc comparisons in the package lsmeans $^{56}$.

\section{Competition for carrion in Gamlingay and Waresley Woods: field data}

486 To test for a difference in the Nicrophorus guild between Gamlingay and Waresley Woods, a frequency table of beetle communities was analysed using permutational multivariate analysis of variance (PERMANOVA) on two-dimensional nonmetric multidimensional scaling (NMDS) based on Bray-Curtis distances ${ }^{57}$, with the 'adonis' function (vegan package). We tested the effect of study site on the composition of the beetle community, using sampling year as strata. The analysis was based on 10000 permutations of the data. We visualized the difference of beetle community between Gamlingay and Waresley population in two dimensions of a NMDS plot. NMDS two-dimensional stress values (a measure of goodness of fit) were below $0.1(0.085)$, indicating the ordination provides a good fit to the data $^{58}$.

We used general linear mixed models (GLMM) with a Poisson error structure to test for differences across beetle species and sites on average abundance for each species per trap. Beetle species and population (Gamlingay/Waresley) were included as fixed effects, whereas trap ID and sampling year were included as random factors. We also tested for differences in the probability of co-occurrence (co-occurring $=1$, non-co-occurring $=0$ ) between $N$. vespilloides and at least one other Nicrophorus spp. across sites using a binomial GLMM. Population was included as a fixed effect and year as a random effect.

We compare the distributions of body size between Gamlingay and Waresley $N$.

505 test, which tests whether the cumulative distributions of two data sets are derived from the same distribution. We also tested for significant differences in mean body size between $N$.

507 vespilloides in Gamlingay and Waresley, using a GLMM that included population

508 (Gamlingay/Waresley) and sex (male/female) as fixed effects, and sampling year as a random 
factor. Differences of mean body size among Nicrophorus spp. was assessed in a GLMM that included species and sex as fixed effects, and sampling year as a random factor.

We analysed the body mass of rodents in Gamlingay and Waresley using a GLM by including rodent species and population (Gamlingay/Waresley) as fixed effects.

515 To test for differences in reproductive performance between species, we conducted a GLMM

516 regression to analyse differences in efficiency (total brood mass divided by carcass mass),

517 which was logit transformed prior to analysis. Beetle species, carcass size (small/large), and

518 their interaction were included as explanatory variables. Sampling year was included as a

519 random factor. In this analysis, we included beetle species as $N$. interruptus, $N$. investigator,

520 Gamlingay N. vespilloides and Waresley N. vespilloides to fully compare differences not only

521 between Nicrophorus beetle species, but also $N$. vespilloides between populations.

\section{Niche expansion in $N$. vespilloides by genetic accommodation}

524 For the reaction norm experiment, we used GLMMs to test the interacting effect of

525 population and carcass size on brood size and average larval mass, with dyad identity nested

526 within block included as a random factor. In all models, brood size and average larval mass

527 were analysed with a Poisson and Gaussian error distribution, respectively. A similar

528 statistical approach was used for analyses of clutch traits to test for the significant differences

529 on clutch size and average egg volume in GLMMs with a Poisson and Gaussian error

530 distribution, respectively. The effect of population of origin, carcass size, and their

531 interaction were included as fixed effects, whereas dyad identity was included as a random

532 factor. If a significant interaction was found, a Tukey's post-hoc test was performed to detect

533 significant effects using multiple pairwise comparisons.

\section{Acknowledgements}

536 We thank P. Pilbeam for carrying out small mammal trapping in the field. We thank A.

537 Attisano, C. Swannack, and R. Mashoodh for helping with beetle trapping. S.-J.S. was 538 supported by the Taiwan Cambridge Scholarship from the Cambridge Commonwealth,

539 European \& International Trust. A.M.C. was supported by a studentship from the National

540 Environmental Research Council's Earth System Sciences Doctoral Training Partnership at

541 Cambridge University and a Victoria Brahm Schild Internship Grant from Homerton College. 
542 R.M.K. was supported by a European Research Council Consolidator's grant 301785

543 BALDWINIAN_BEETLES and a Wolfson Merit Award from the Royal Society.

544

545 Author Contributions

546 R.M.K. conceived the idea. S.-J.S., A.M.C. S.P. and R.M.K designed the study. S.-J.S.,

547 A.M.C. and B.J.M.J. acquired the phenotypic data, which was analysed by S.-J.S. and

548 A.M.C. M.J.S. and S.P. designed the genetic's component, which was collected by S.P. and

549 analysed by M.J.S and S.E.M. All authors contributed to discussion of the results and writing

550 the manuscript.

552 Competing Interests Statement

553 The authors declare no competing interests.

\section{References}

556 1. Baldwin, M. A new factor in evolution. Am. Nat. 30, 441-451 (1896).

2. Morgan, C. L. On modification and variation. Science 4, 733-740 (1896).

3. Robinson, B. W. \& Dukas, R. The influence of phenotypic modifications on evolution: the Baldwin effect and modern perspectives. Oikos 85, 582 (1999).

4. West-Eberhard, M. J. Developmental plasticity and evolution. (Oxford University Press, 2003).

562 5. Pfennig, D. W. et al. Phenotypic plasticity's impacts on diversification and speciation. 563 Trends Ecol. Evol. 25, 459-467 (2010).

564 6. Levis, N. A. \& Pfennig, D. W. Evaluating 'plasticity-first' evolution in nature: key criteria and empirical approaches. Trends Ecol. Evol. 31, 563-574 (2016).

566 7. Levis, N. A., Isdaner, A. J. \& Pfennig, D. W. Morphological novelty emerges from pre-existing phenotypic plasticity. Nat. Ecol. Evol. 2, 1289-1297 (2018).

8. Corl, A. et al. The genetic basis of adaptation following plastic changes in coloration in a novel environment. Curr. Biol. 28, 2970-2977.e7 (2018).

570 9. Waddington, C. H. Genetic assimilation of an acquired character. Evolution. 7, 118- 
126 (1953).

572

573

574

10. Lenormand, T. Gene flow and the limits to natural selection. Trends Ecol. Evol. 17, 183-189 (2002).

11. Sultan, S. E. \& Spencer, H. G. Metapopulation structure favors plasticity over local adaptation. Am. Nat. 160, 271-83 (2002).

12. Crispo, E. Modifying effects of phenotypic plasticity on interactions among natural selection, adaptation and gene flow. J. Evol. Biol. 21, 1460-1469 (2008).

13. West-Eberhard, M. J. Developmental plasticity and the origin of species differences. Proc. Natl. Acad. Sci. U. S. A. 102 Suppl, 6543-9 (2005).

14. Thompson, J. N. Relentless evolution. (University of Chicago Press, 2013).

15. Bock, D. G., Kantar, M. B., Caseys, C., Matthey-Doret, R. \& Rieseberg, L. H. Evolution of invasiveness by genetic accommodation. Nat. Ecol. Evol. 2, 991-999 (2018).

16. Pascoal, S. \& Kilner, R. M. Development and application of 14 microsatellite markers in the burying beetle Nicrophorus vespilloides reveals population genetic differentiation at local spatial scales. PeerJ 5, e3278 (2017).

17. Rackham, O. The history of the countryside : the classic history of Britain's landscape, flora and fauna. (Phoenix Press, 2000).

18. Scott, M. P. The ecology and behavior of burying beetles. Annu. Rev. Entomol 43, 595-618 (1998).

19. Otronen, M. The effects of body size on the outcome of Fig.hts in burying beetles (Nicrophorus). Ann. Zool. Fennici 25, 191-201 (1988).

20. Safryn, S. A. \& Scott, M. P. Sizing up the competition: do burying beetles weigh or measure their opponents? J. Insect Behav. 13, 291-297 (2000).

Urbański, A. \& Baraniak, E. Differences in early seasonal activity of three burying beetle species (Coleoptera: Silphidae: Nicrophorus F.) in Poland. Coleopt. Bull. 69, 283-292 (2015). 
598

599

600

601

602

603

604

605

606

607

608

609

610

611

612

613

614

615

616

617

618

619

620

22. Müller, J. K., Eggert, A.-K. \& Furlkröger, E. Clutch size regulation in the burying beetle Necrophorus vespilloides Herbst (Coleoptera: Silphidae). J. Insect Behav. 3, 265-270 (1990).

23. Bartlett, J. Filial cannibalism in burying beetles. Behav. Ecol. Sociobiol. 21, 179-183 (1987).

24. Gibbs, J. P. \& Stanton, E. J. Habitat fragmentation and arthropod community change: carrion Beetles, phoretic mites, and flies. Ecol. Appl. 11, 79 (2001).

25. Lomolino, M. V. Ecology's most general, yet protean 1 pattern: the species-area relationship. J. Biogeogr. 27, 17-26 (2000).

26. Smith, R. J. \& Heese, B. Carcass selection in a high altitude population of the burying beetle, Nicrophorus investigator (Silphidae). Southwest. Nat. 40, 50-55 (1995).

27. Hopwood, P. E., Moore, A. J., Tregenza, T. \& Royle, N. J. Niche variation and the maintenance of variation in body size in a burying beetle. Ecol. Entomol. 41, 96-104 (2016).

28. Russell, A. F., Langmore, N. E., Cockburn, A., Astheimer, L. B. \& Kilner, R. M. Reduced egg investment can conceal helper effects in cooperatively breeding birds. Science 317, 941-944 (2007).

29. Smiseth, P. T., Andrews, C. P., Mattey, S. N. \& Mooney, R. Phenotypic variation in resource acquisition influences trade-off between number and mass of offspring in a burying beetle. J. Zool. 293, 80-83 (2014).

30. Schrader, M., Jarrett, B. J. M. \& Kilner, R. M. Parental care masks a densitydependent shift from cooperation to competition among burying beetle larvae. Evolution. 69, 1077-1084 (2015).

31. Lock, J. E., Smiseth, P. T. \& Moore, A. J. Selection, inheritance, and the evolution of parent-offspring interactions. Am. Nat. 164, 13-24 (2004).

32. Yi, X. et al. Sequencing of 50 human exomes reveals adaptation to high altitude. Science 329, 75-8 (2010). 
625

626

627

628

629

630

631

632

633

634

635

636

637

638

639

640

641

642

643

644

645

646

33. Fumagalli, M. et al. Greenlandic Inuit show genetic signatures of diet and climate adaptation. Science 349, 1343-1347 (2015).

34. Chintapalli, V. R., Al Bratty, M., Korzekwa, D., Watson, D. G. \& Dow, J. A. T. Mapping an atlas of tissue-specific Drosophila melanogaster metabolomes by high resolution mass spectrometry. PLoS One 8, e78066 (2013).

35. Cao, X. \& Jiang, H. An analysis of 67 RNA-seq datasets from various tissues at different stages of a model insect, Manduca sexta. BMC Genomics 18, 796 (2017).

36. Ghiglione, C. et al. The transmembrane molecule kekkon 1 acts in a feedback loop to negatively regulate the activity of the Drosophila EGF receptor during oogenesis. Cell 96, 847-56 (1999).

37. Wittes, J. \& Schüpbach, T. A gene expression screen in Drosophila melanogaster identifies novel JAK/STAT and EGFR targets during oogenesis. G3 Genes, Genomes, Genet. 9, 47-60 (2019).

38. Scoville, A. G. \& Pfrender, M. E. Phenotypic plasticity facilitates recurrent rapid adaptation to introduced predators. Proc. Natl. Acad. Sci. U. S. A. 107, 4260-3 (2010).

39. Rackham, O. Trees and woodland in the British landscape. (Phoenix Giant, 1996).

40. Adamson, R. S. An ecological study of a Cambridgeshire woodland. J. Linn. Soc. London, Bot. 40, 339-387 (1912).

41. Darby, H. C. Domesday woodland. Econ. Hist. Rev. 3, 21 (1950).

42. Jackson, D. M., Trayhurn, P. \& Speakman, J. R. Associations between energetics and over-winter survival in the short-tailed field vole Microtus agrestis. J. Anim. Ecol. 70, $633-640$ (2001).

43. Berrigan, D. The allometry of egg size and number in insects. Oikos 60, 313 (1991).

44. Li, H. \& Durbin, R. Fast and accurate short read alignment with Burrows-Wheeler transform. Bioinformatics 25, 1754-1760 (2009).

45. Van der Auwera, G. A. et al. in Current Protocols in Bioinformatics 43, 11.10.111.10.33 (John Wiley \& Sons, Inc., 2013). 
46. Bradbury, P. J. et al. TASSEL: software for association mapping of complex traits in diverse samples. Bioinformatics 23, 2633-2635 (2007).

47. Korneliussen, T. S., Albrechtsen, A. \& Nielsen, R. ANGSD: Analysis of Next Generation Sequencing Data. BMC Bioinformatics 15, 356 (2014).

48. Woodring, J. \& Hoffmann, K. H. The effects of octopamine, dopamine and serotonin on juvenile hormone synthesis, In vitro, in the cricket, Gryllus bimaculatus. J. Insect Physiol. 40, 797-802 (1994).

49. Shimada-Niwa, Y. \& Niwa, R. Serotonergic neurons respond to nutrients and regulate the timing of steroid hormone biosynthesis in Drosophila. Nat. Commun. 5, 5778 (2014).

50. Cook, C. N., Lawson, S. P., Brent, C. S. \& Rehan, S. M. Biogenic amines shift during the pre-reproductive to reproductive transition in the small carpenter bee, Ceratina calcarata. Apidologie 50, 90-99 (2019).

51. Dierick, H. A. \& Greenspan, R. J. Serotonin and neuropeptide F have opposite modulatory effects on fly aggression. Nat. Genet. 39, 678-682 (2007).

52. Aleksandrowicz, O. \& Komosiński, K. in Protection of Coleoptera in the Baltic Sea Region (ed. J. Skłodowski, S. Huruk, A. Barševskis, S. T.) 147-153 (Warsaw Agricultural University Press, 2005).

53. Bubak, A. N., Renner, K. J. \& Swallow, J. G. Heightened serotonin influences contest outcome and enhances expression of high-intensity aggressive behaviors. Behav. Brain Res. 259, 137-142 (2014).

54. Stevenson, P. A. \& Rillich, J. Controlling the decision to Fig.ht or flee: the roles of biogenic amines and nitric oxide in the cricket. Curr. Zool. 62, 265-275 (2016).

55. Bates, D., Maechler, M., Bolker, B. \& Walker, S. Fitting linear mixed-effects models using lme4. R package version 1.0-6 (2015).

56. Lenth, R. V. Least-squares means: the R package lsmeans. J. Stat. Softw. 69, 1-33 (2016). 
679 57. Clarke, K. R. Non-parametric multivariate analyses of changes in community

680 structure. Aust. J. Ecol. 18, 117-143 (2016).

681 58. Ramette, A. Multivariate analyses in microbial ecology. FEMS Microbiol. Ecol. 62, $682 \quad 142-160(2007)$. 
a

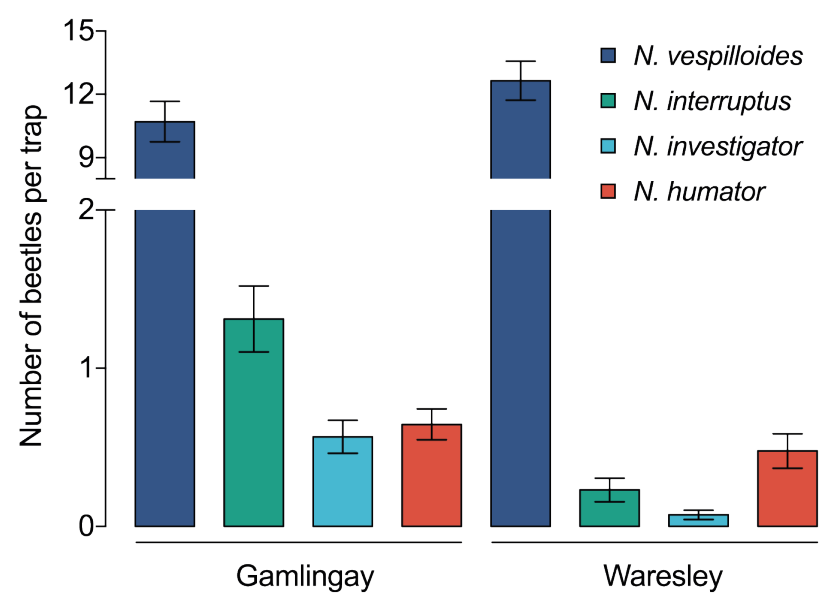

b

N. vespilloides

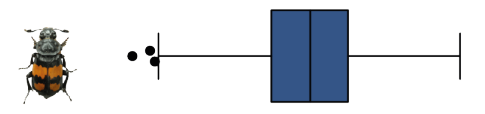

N. interruptus

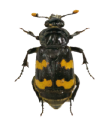

N. investigator

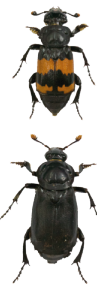

N. humator woodlands. Error bars indicate mean \pm S.E.M.
C
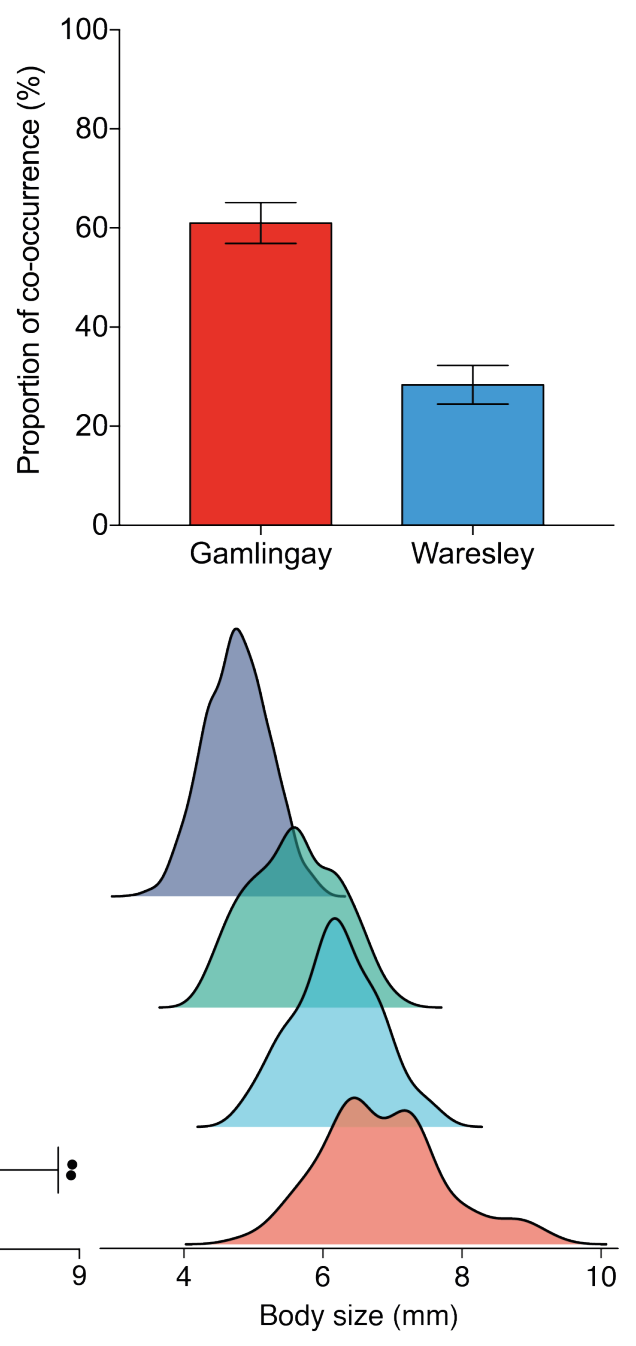

Figure 1. a, Number of Nicrophorus beetles caught per trap from 2014-2017. b, Body size and frequency distribution of field-caught Nicrophorus spp., illustrated withbox-and-whisker plots (left) and kernel density estimation (right). Points indicate outliers. c, The proportion of traps set at which $N$. vespilloides was trapped with another Nicrophorus species, in the two 


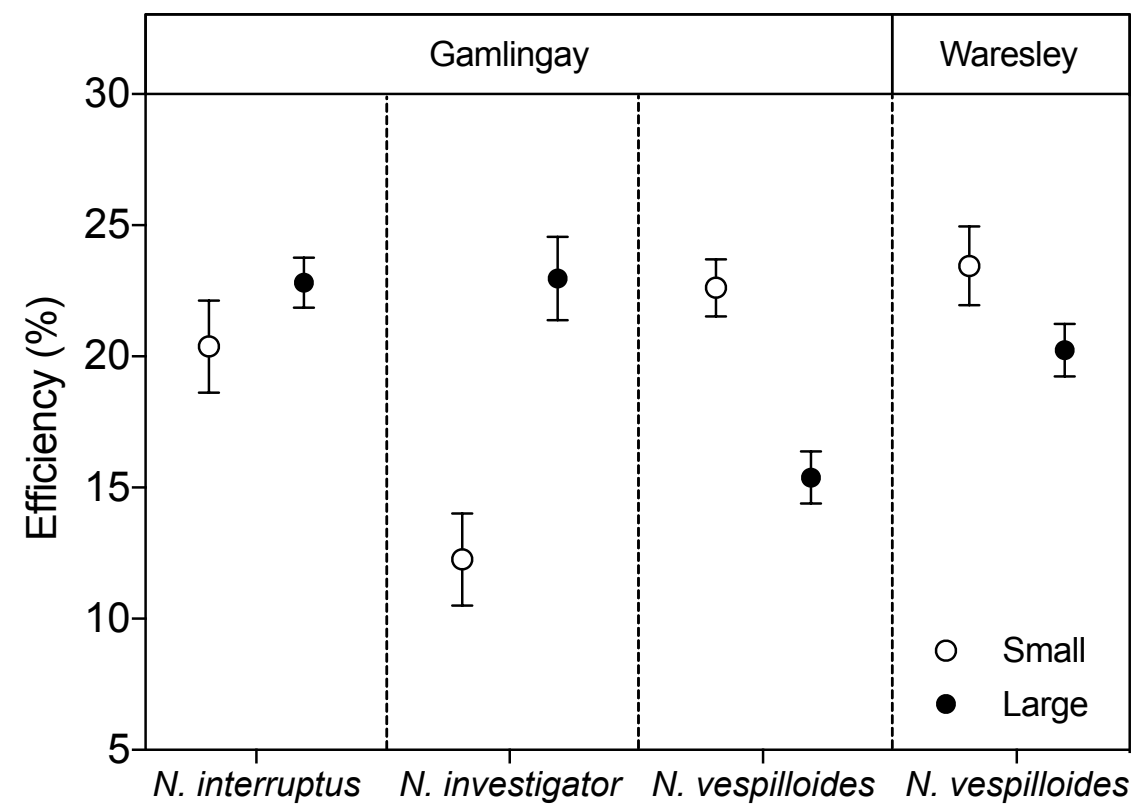

697 Figure 2. Efficiency (\%) of carcass use (total brood mass divided by carcass mass) of $N$.

698 interruptus, N. investigator, and N. vespilloides from Gamlingay Wood and N. vespilloides 699 from Waresley Wood. Values represent the mean \pm S.E.M. 
a b

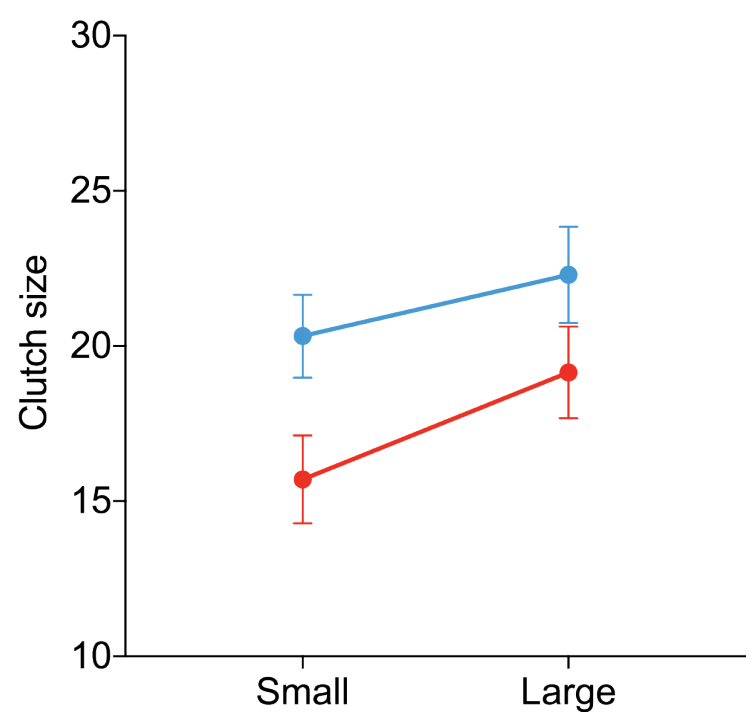

Figure 3. The effect of carcass size on (a) clutch size and (b) average egg volume produced by $N$. vespilloides. $n=27$ Gamlingay $N$. vespilloides per carcass size treatment, and $n=37$ Waresley $N$. vespilloides per carcass size treatment. Values represent the mean \pm S.E.M. 
a

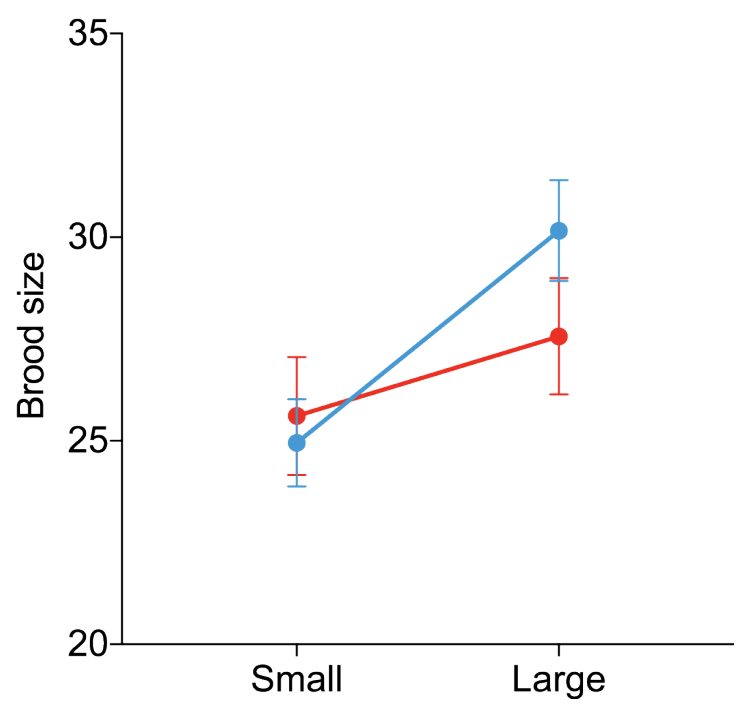

b

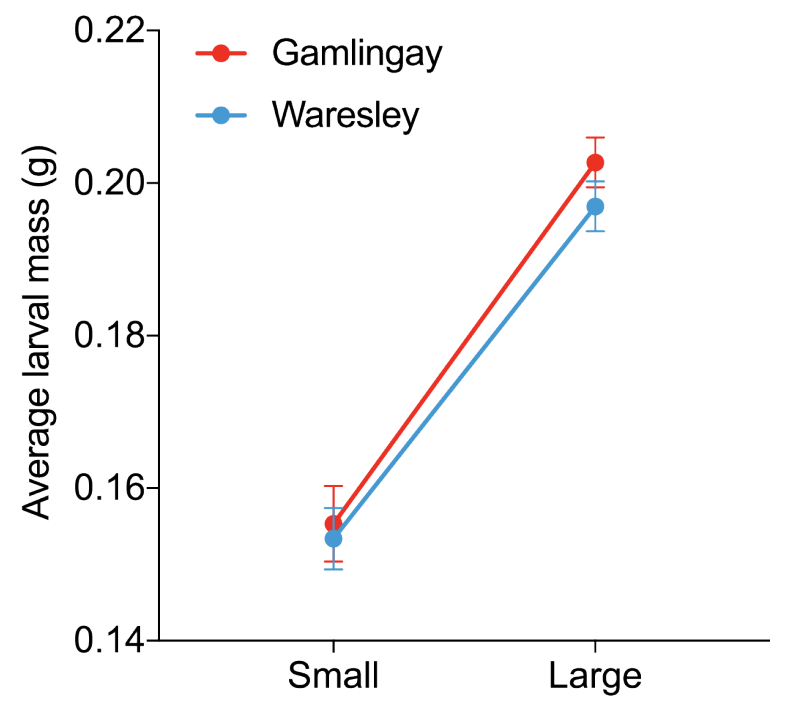

Figure 4. The effect of carcass size on (a) brood size and (b) average larval mass for $N$. size treatment, and $n=62$ Waresley $N$. vespilloides per carcass size treatment). Values represent the mean \pm S.E.M. 
a
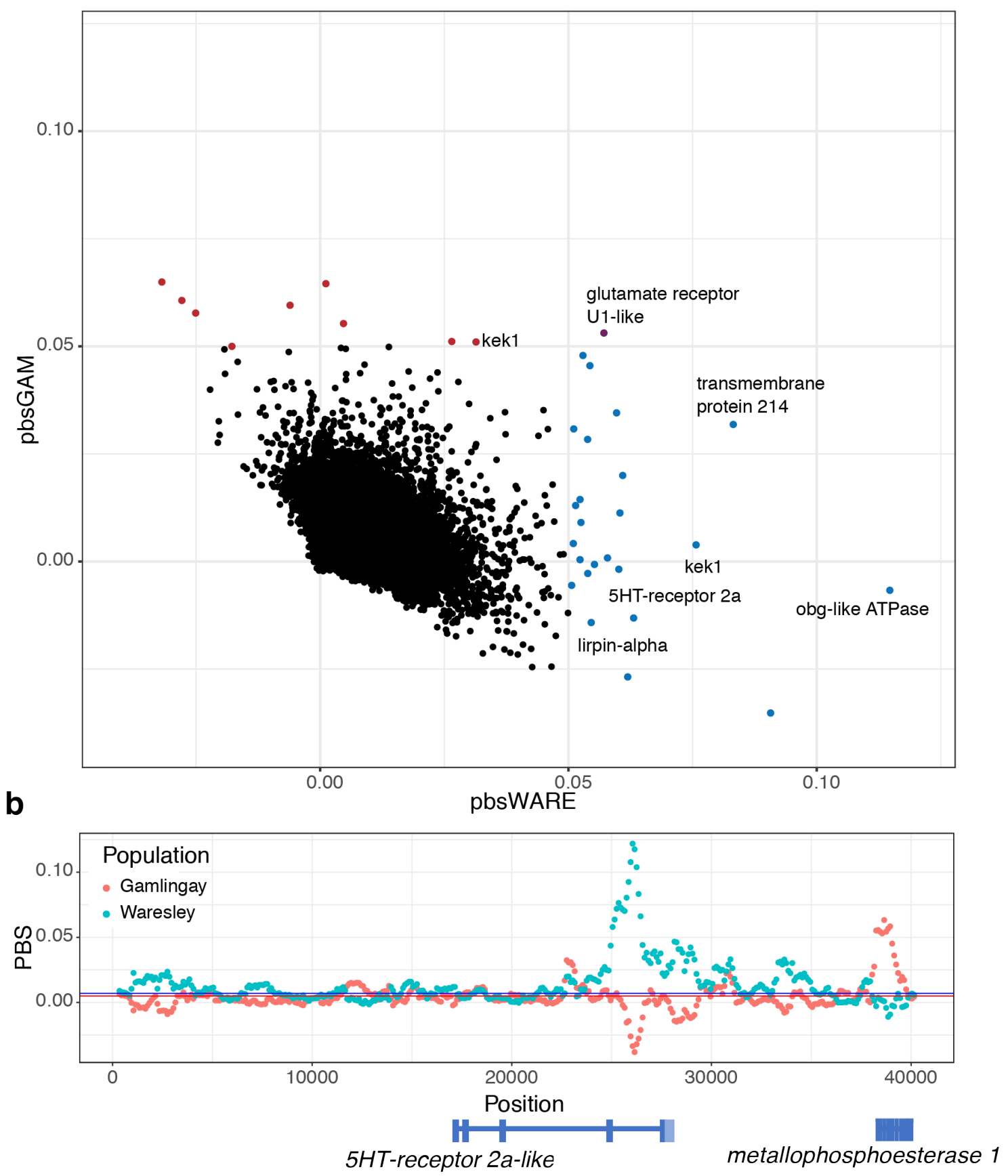

721 Figure 5. Differentiation at putative oogenesis genes. a, A scatterplot of PBS values for Waresley and Gamlingay in $2 \mathrm{~kb}$ windows genome-wide. Loci in the lower right hand of the figure show high differentiation in Waresley but not in Gamlingay. Loci with PBS scores greater than 0.05 are highlighted - Waresley $=$ blue, Gamlingay $=$ red, Both $=$ purple. Notable genes are annotated. $\mathbf{b}$, Sliding window analysis ( window $=500 \mathrm{bp}$, slide $=100 \mathrm{bp}$ ) of PBS values at the $5 H T$ receptor 2a-like receptor. The peak PBS in Waresley (blue) falls in the last intron of the gene. 
Table 1. Population differences in enrichment scores in multiple GO terms associated with ovaries and oogenesis.

\begin{tabular}{|c|c|c|c|c|c|c|c|c|}
\hline \multirow[b]{2}{*}{ GO ID } & \multirow[b]{2}{*}{ GO Name } & \multirow[b]{2}{*}{ Size } & \multicolumn{2}{|c|}{ Waresley } & \multicolumn{2}{|c|}{ Gamling } & \multicolumn{2}{|c|}{ Wales } \\
\hline & & & NES & FDR q-val & NES & FDR q-val & NES & FDR q-val \\
\hline GO:0030707 & ovarian follicle cell development & 345 & 3.36 & $0.00 \mathrm{E}+00$ & 3.27 & $1.2 \mathrm{E}-05$ & 2.52 & $1.35 \mathrm{E}-03$ \\
\hline GO:0007297 & ovarian follicle cell migration & 129 & 3.32 & $0.00 \mathrm{E}+00$ & 2.86 & $1.0 \mathrm{E}-04$ & 3.09 & 4.10E-05 \\
\hline GO:1905879 & regulation of oogenesis & 66 & 2.22 & $7.31 \mathrm{E}-03$ & 2.07 & $1.4 \mathrm{E}-02$ & & \\
\hline GO:0048599 & $\begin{array}{l}\text { oocyte development } \\
\text { chorion-containing eggshell }\end{array}$ & 165 & 2.16 & $9.70 \mathrm{E}-03$ & 1.83 & 4.1E-02 & & \\
\hline GO:0007304 & formation & 78 & 2.12 & $1.20 \mathrm{E}-02$ & 2.41 & $2.0 \mathrm{E}-03$ & & \\
\hline GO:0007308 & oocyte construction & 157 & 2.07 & $1.55 \mathrm{E}-02$ & 1.83 & $4.2 \mathrm{E}-02$ & & \\
\hline GO:0030703 & eggshell formation & 79 & 2.04 & $1.80 \mathrm{E}-02$ & 2.50 & $1.3 \mathrm{E}-03$ & & \\
\hline GO:1905881 & positive regulation of oogenesis & 37 & 2.04 & $1.83 \mathrm{E}-02$ & & & & \\
\hline GO:0009994 & oocyte differentiation & 194 & 2.01 & $2.05 \mathrm{E}-02$ & 2.25 & $5.1 \mathrm{E}-03$ & & \\
\hline GO:0007309 & oocyte axis specification & 145 & 1.90 & $3.44 \mathrm{E}-02$ & 1.85 & $3.9 \mathrm{E}-02$ & & \\
\hline GO:0030728 & ovulation & 11 & 1.83 & $4.58 \mathrm{E}-02$ & & & & \\
\hline GO:0007306 & eggshell chorion assembly & 66 & & & 2.04 & $1.6 \mathrm{E}-02$ & & \\
\hline GO:0060281 & regulation of oocyte development & 29 & & & 1.79 & $4.9 \mathrm{E}-02$ & & \\
\hline
\end{tabular}


a

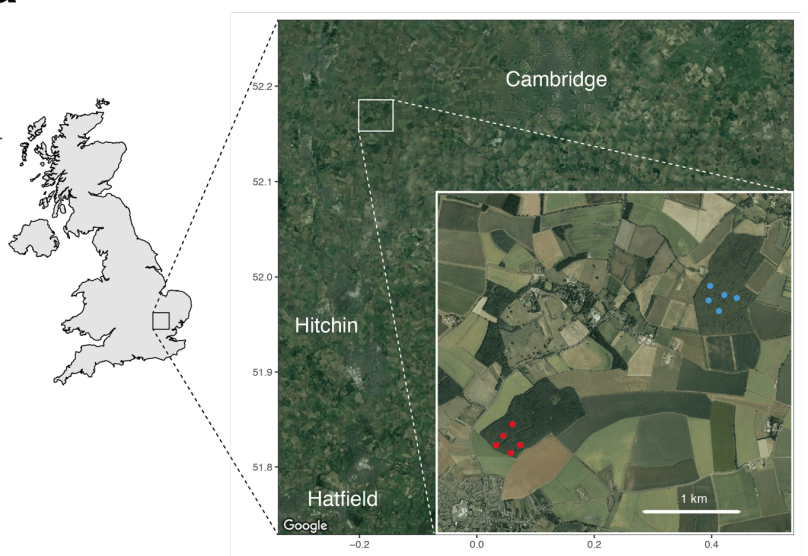

b

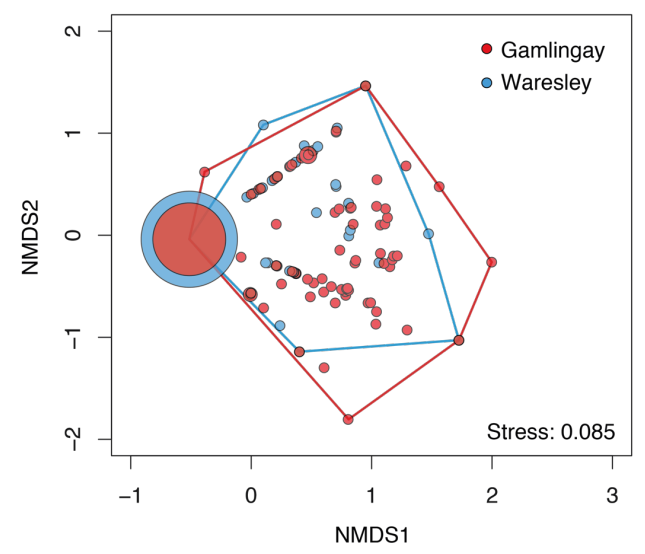

Supplementary Fig. 1. Study sites and population differences in community structure. a, Location of traps in Gamlingay Wood (red points) and Waresley Wood (blue points). b, NMDS ordination of Gamlingay $(n=141)$ and Waresley $(n=134)$ community structure. Each point represents the sum of the beetle community collected in each trap per sampling time. 
bioRxiv preprint doi: https://doi.org/10.1101/598292; this version posted May 10, 2019. The copyright holder for this preprint (which was not certified by peer review) is the author/funder, who has granted bioRxiv a license to display the preprint in perpetuity. It is made available under

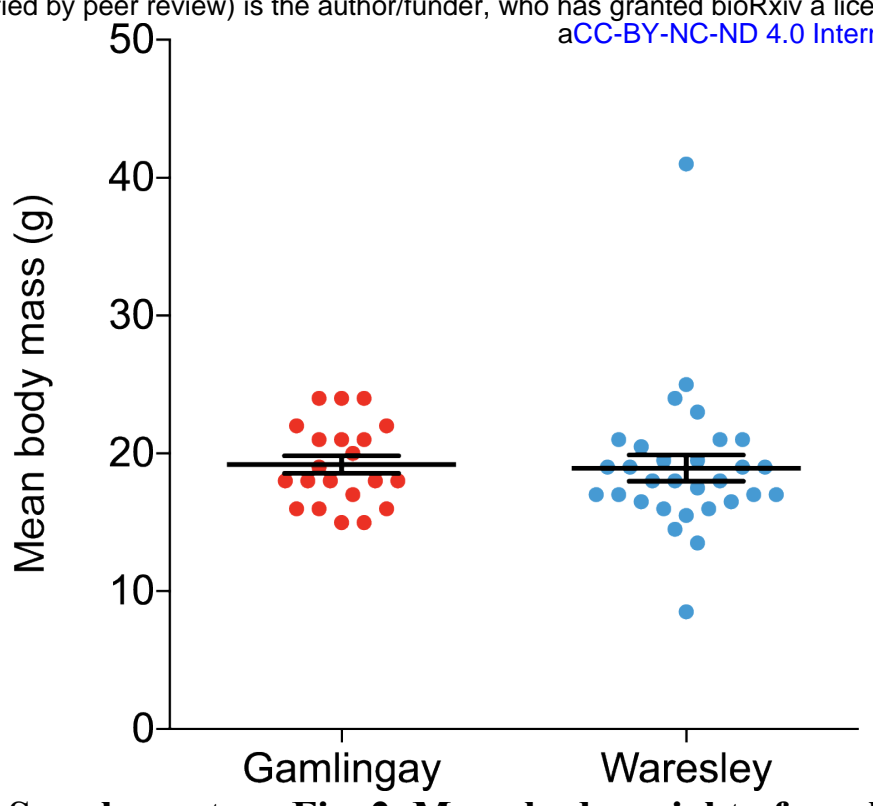

Supplementary Fig. 2. Mean body weight of small mammals. Gamlingay ( $n=21$, red) and

Waresley Woods ( $n=30$, blue). One bank vole and one wood mouse, each caught in in

Gamlingay Wood, escaped before they could be measured. 
bioRxiv preprint doi: https://doi.org/10.1101/598292; this version posted May 10, 2019. The copyright holder for this preprint (which was not certified by peer review) is the author/funder, who has granted bioRxiv a license to display the preprint in perpetuity. It is made available under

a

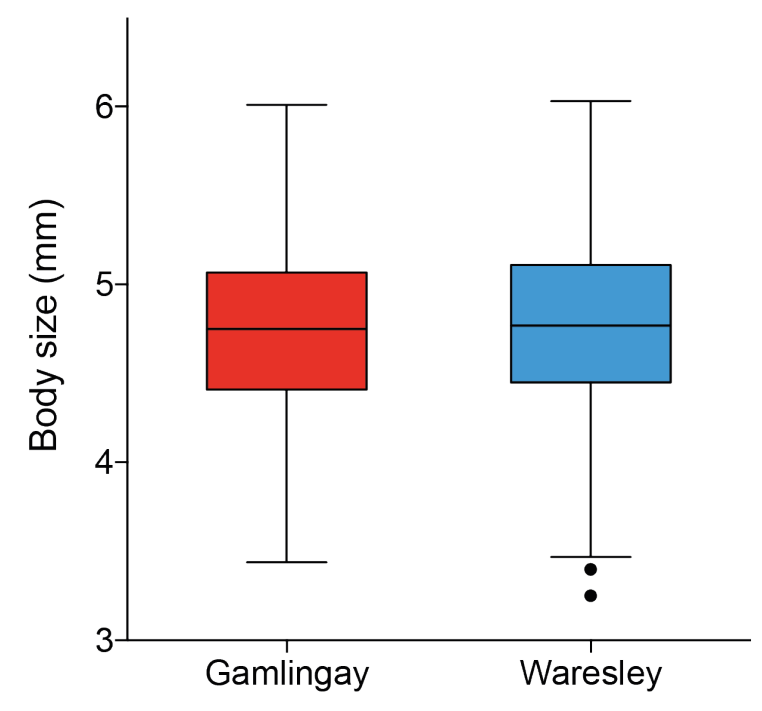

nternational license.

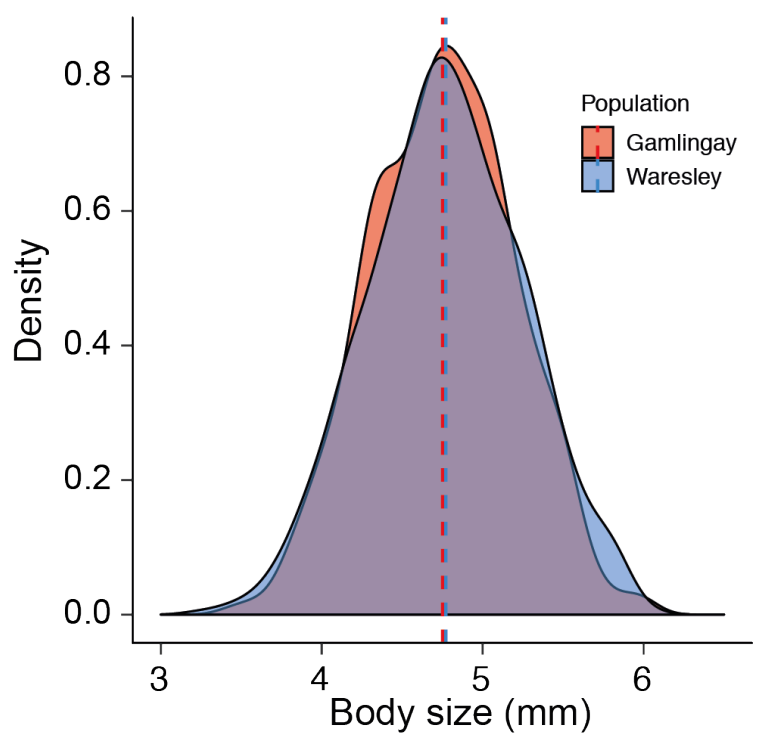

\section{Supplementary Fig. 3. Differences in (a) body size and (b) frequency distribution of}

field-caught $N$. vespilloides from Gamlingay and Waresley Woods. Measurements depict pronotum width, the standard index for measuring beetle body size. Median values, interquartile range, maximum, and minimum are as illustrated in box-and-whisker plots. Outliers are depicted as points. Number of $N$. vespilloides sampled: Gamlingay $(n=839)$ and Waresley Woods $(n=824)$. 
bioRxiv preprint doi: https://doi.org/10.1101/598292; this version posted May 10, 2019. The copyright holder for this preprint (which was not certified by peer review) is the author/funder, who has granted bioRxiv a license to display the preprint in perpetuity. It is made available under aCC-BY-NC-ND 4.0 International license.

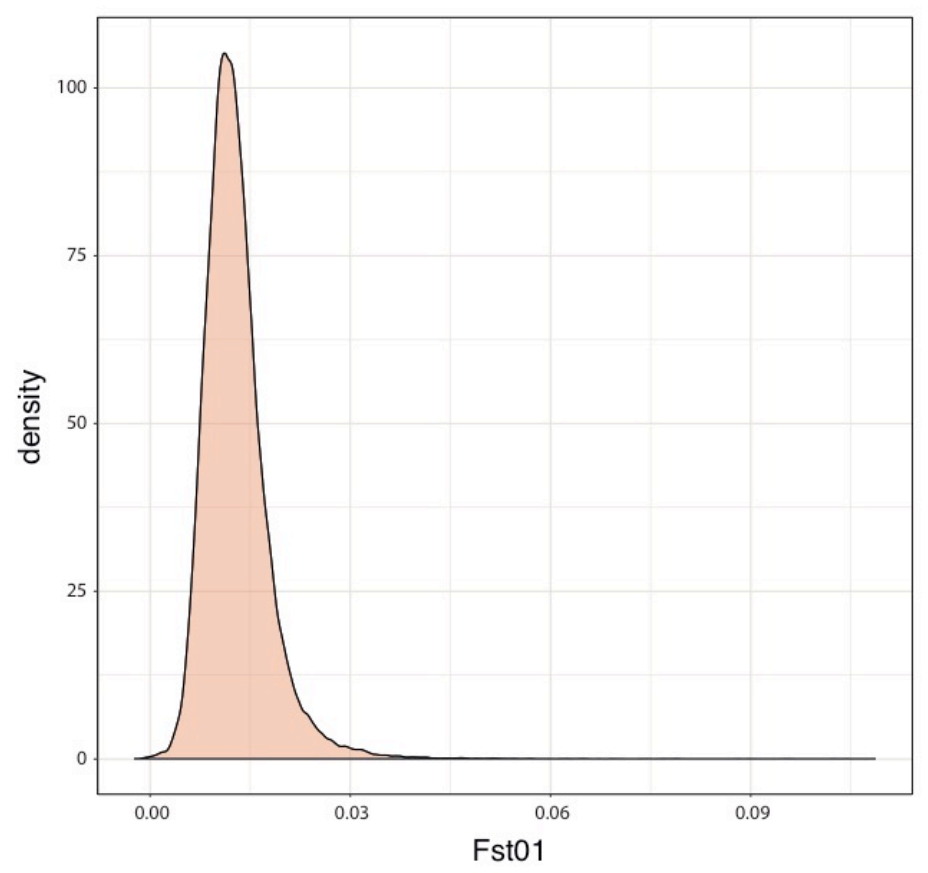

Supplementary Fig. 4. Density plot of Fst value between Gamlingay and Waresley

Woods. The plot shows the narrow distribution of low Fst values between the two woodland populations. Though there is a long tail to the right, the extreme values are modest in absolute terms. 
bioRxiv preprint doi: https://doi.org/10.1101/598292; this version posted May 10, 2019. The copyright holder for this preprint (which was not certified by peer review) is the author/funder, who has granted bioRxiv a license to display the preprint in perpetuity. It is made available under

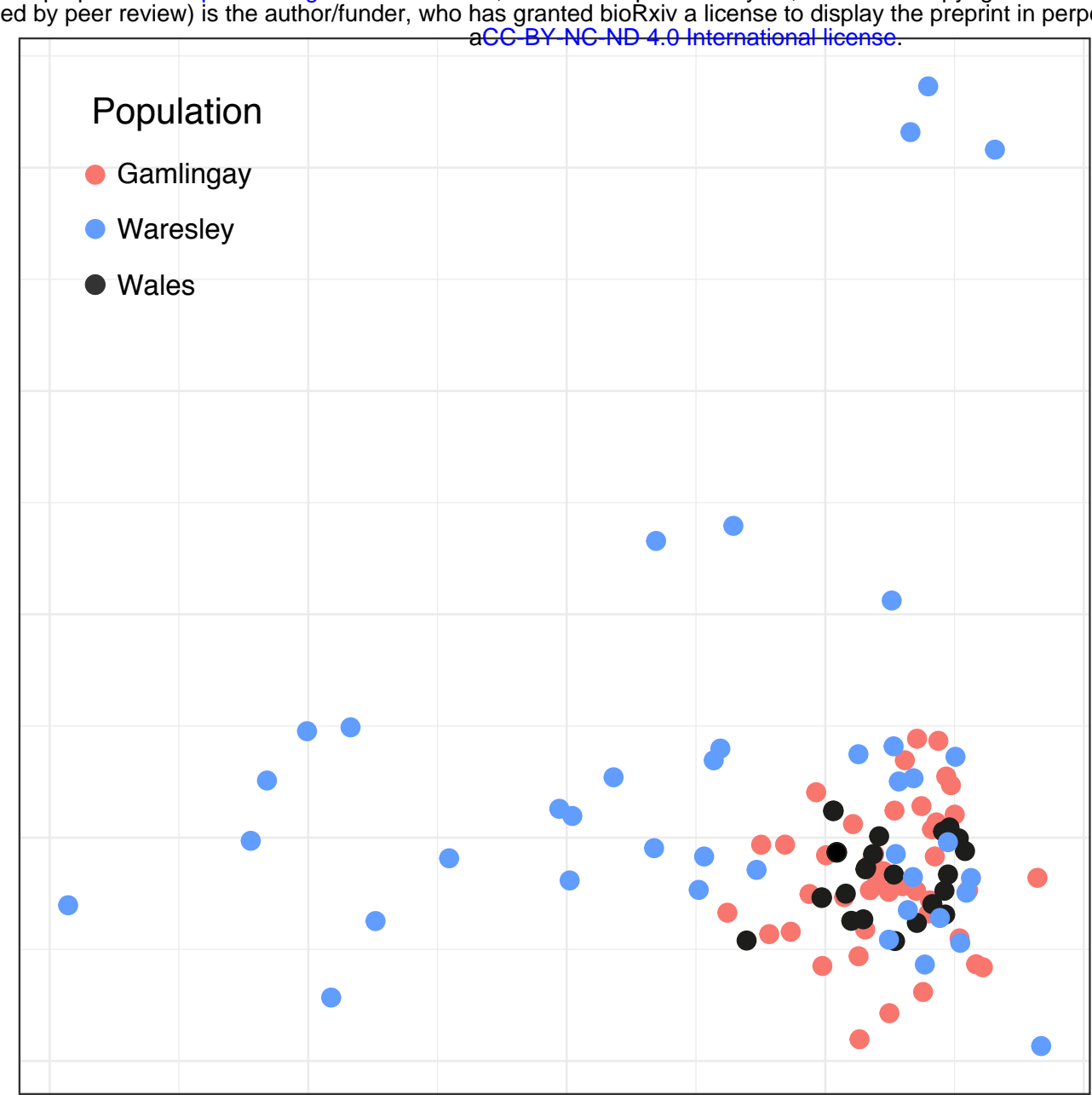

Supplementary Fig. 5. MDS plot of three burying beetle populations. The plot shows the first two dimensions of a multidimensional scaling analysis of genetic diversity among burying beetles in three populations. The populations do not separate out, indicating little to no genetic structure. 
bioRxiv preprint doi: https://doi.org/10.1101/598292; this version posted May 10, 2019. The copyright holder for this preprint (which was not certified by peer review) is the author/funder, who has granted bioRxiv a license to display the preprint in perpetuity. It is made available under

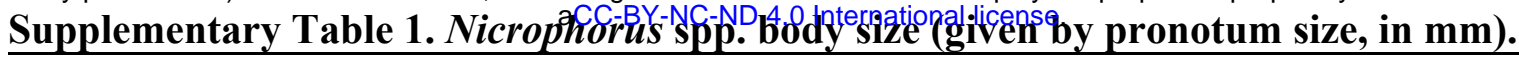

\begin{tabular}{lllllllll}
\hline \hline Species & $\boldsymbol{N}$ & Mean & SD & Minimum & Q1 & Median & Q3 & Maximum \\
\hline N. vespilloides & 1662 & 4.76 & 0.46 & 3.25 & 4.43 & 4.76 & 5.08 & 6.03 \\
N. interruptus & 152 & 5.59 & 0.64 & 4.28 & 5.10 & 5.60 & 6.10 & 7.07 \\
N. investigator & 58 & 6.19 & 0.61 & 4.89 & 5.80 & 6.18 & 6.58 & 7.59 \\
N. humator & 92 & 6.86 & 0.89 & 4.85 & 6.30 & 6.75 & 7.31 & 9.25 \\
N. vespillo & 11 & 5.74 & 0.59 & 4.86 & 5.44 & 5.76 & 5.98 & 6.93 \\
\hline
\end{tabular}

$(N)$ : Number of Nicrophorus spp.; (SD): Standard Deviation; 25\% (Q1): Quantile; (Q3): 75\% Quantile. 
bioRxiv preprint doi: https://doi.org/10.1101/598292; this version posted May 10, 2019. The copyright holder for this preprint (which was not certified by peer review) is the author/funder, who has granted bioRxiv a license to display the preprint in perpetuity. It is made available under

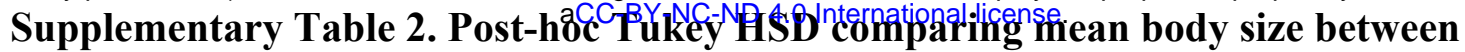

Nicrophorus spp.

\begin{tabular}{lllllllll}
\hline \hline \multirow{2}{*}{ Species } & \multicolumn{2}{l}{$\boldsymbol{N}$. vespilloides } & \multicolumn{2}{l}{ N. interruptus } & \multicolumn{2}{l}{ N. investigator } & \multicolumn{2}{l}{ N. humator } \\
\cline { 2 - 11 } & $t$ & $p$ & $t$ & $p$ & $t$ & $p$ & $t$ & $p$ \\
\hline$N$. interruptus & 18.69 & $<\mathbf{0 . 0 0 1}$ & - & - & - & - & - & - \\
$N$. investigator & 20.62 & $<\mathbf{0 . 0 0 1}$ & -7.61 & $<\mathbf{0 . 0 0 1}$ & - & - & - & - \\
$N$. humator & 38.15 & $<\mathbf{0 . 0 0 1}$ & 18.54 & $<\mathbf{0 . 0 0 1}$ & 7.69 & $<\mathbf{0 . 0 0 1}$ & - & - \\
$N$. vespillo & 6.31 & $<\mathbf{0 . 0 0 1}$ & -0.93 & 0.268 & 2.68 & 0.058 & 6.85 & $<\mathbf{0 . 0 0 1}$ \\
\hline
\end{tabular}

$p$ values $<0.05$ are highlighted in bold. Dashes indicate comparisons that were not made. 
bioRxiv preprint doi: https://doi.org/10.1101/598292; this version posted May 10, 2019. The copyright holder for this preprint (which was not certified by peer review) is the author/funder, who has granted bioRxiv a license to display the preprint in perpetuity. It is made available under

Supplementary Table 3. Results of the ANO

Nicrophorus spp.

\begin{tabular}{lllll}
\hline \hline $\begin{array}{l}\text { Dependent } \\
\text { variable }\end{array}$ & Explanatory variables & $\boldsymbol{\chi}^{\mathbf{2}}$ & d.f. & $\boldsymbol{p}$ value \\
\hline Efficiency $(\%)$ & Carcass size & 17.26 & 1 & $<\mathbf{0 . 0 0 1}$ \\
& Beetle species & 20.42 & 3 & $<\mathbf{0 . 0 0 1}$ \\
& Carcass size x Beetle species & 28.85 & 3 & $<\mathbf{0 . 0 0 1}$ \\
\hline
\end{tabular}

$p$ values $<0.05$ are highlighted in bold. 
bioRxiv preprint doi: https://doi.org/10.1101/598292; this version posted May 10, 2019. The copyright holder for this preprint (which was not certified by peer review) is the author/funder, who has granted bioRxiv a license to display the preprint in perpetuity. It is made available under

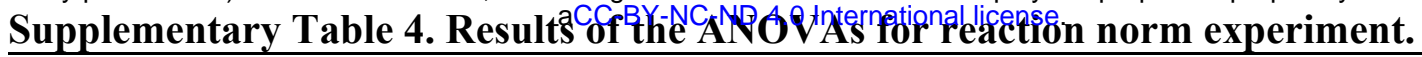

\begin{tabular}{lllll}
\hline \hline Dependent variable & Explanatory variables & $\chi^{2}$ & d.f. & $\boldsymbol{p}$ value \\
\hline Brood size & Carcass size & 3.33 & 1 & 0.068 \\
& Population & 3.89 & 1 & $\mathbf{0 . 0 4 8}$ \\
& Carcass size x Population & 4.80 & 1 & $\mathbf{0 . 0 2 9}$ \\
\hline Average larval mass & Carcass size & 139.05 & 1 & $<\mathbf{0 . 0 0 1}$ \\
& Population & 1.06 & 1 & 0.304 \\
\hline Clutch size & Carcass size & 11.33 & 1 & $<\mathbf{0 . 0 0 1}$ \\
& Population & 21.07 & 1 & $<\mathbf{0 . 0 0 1}$ \\
\hline \multirow{2}{*}{ Average egg volume } & Female size & 4.26 & 1 & $\mathbf{0 . 0 3 9}$ \\
& Carcass size & 5.90 & 1 & $\mathbf{0 . 0 1 5}$ \\
\hline \multirow{2}{*}{ Total egg volume } & Population & 4.59 & 1 & $\mathbf{0 . 0 3 2}$ \\
& Carcass size & 2.38 & 1 & 0.123 \\
\hline$p$ values $<0.05$ are & Population & 2.16 & 1 & 0.141 \\
\hline
\end{tabular}

$p$ values $<0.05$ are highlighted in bold. 
bioRxiv preprint doi: https://doi.org/10.1101/598292; this version posted May 10, 2019. The copyright holder for this preprint (which was not certified by peer review) is the author/funder, who has granted bioRxiv a license to display the preprint in perpetuity. It is made available under

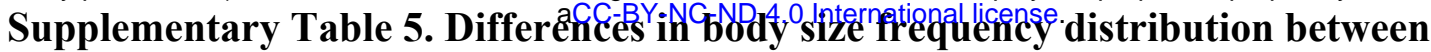

Nicrophorus spp.

\begin{tabular}{lllllllll}
\hline \hline \multirow{2}{*}{ Species } & \multicolumn{2}{l}{$\boldsymbol{N}$. vespilloides } & \multicolumn{2}{l}{$\boldsymbol{N}$. interruptus } & \multicolumn{2}{l}{ N. investigator } & \multicolumn{2}{l}{ N. humator } \\
\cline { 2 - 11 } & $D$ & $p$ & $D$ & $p$ & $D$ & $p$ & $D$ & $p$ \\
\hline N. interruptus & 0.54 & $<\mathbf{0 . 0 0 1}$ & - & - & - & - & - & - \\
N. investigator & 0.81 & $<\mathbf{0 . 0 0 1}$ & 0.41 & $<\mathbf{0 . 0 0 1}$ & - & - & - & - \\
N. humator & 0.91 & $<\mathbf{0 . 0 0 1}$ & 0.62 & $<\mathbf{0 . 0 0 1}$ & 0.38 & $<\mathbf{0 . 0 0 1}$ & - & - \\
N. vespillo & 0.70 & $<\mathbf{0 . 0 0 1}$ & 0.31 & 0.268 & 0.43 & 0.061 & 0.69 & $<\mathbf{0 . 0 0 1}$ \\
\hline
\end{tabular}

$\mathrm{D}$ statistic and corresponding $p$-values from Kolmogorov-Smirnov tests. $p$ values $<0.05$ are highlighted in bold. Dashes indicate comparisons that were not made. 
bioRxiv preprint doi: https://doi.org/10.1101/598292; this version posted May 10, 2019. The copyright holder for this preprint (which was not certified by peer review) is the author/funder, who has granted bioRxiv a license to display the preprint in perpetuity. It is made available under

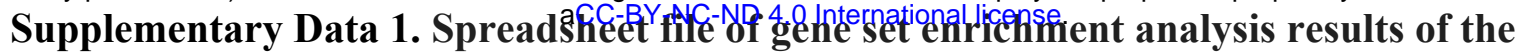
multiple GO terms for Gamlingay and Waresley $N$. vespilloides. 